Агольцов Валерий Александрович, $\partial-p$ вет. наук, проф. кафедры «Болезни животных и ветеринарно-санитарная экспертиза», Саратовский государственный аграрный университет имени Н.И. Вавилова. Россия.

Попова Ольга Михайловна, $\partial-p$ биол. наук, доиент, зав. кафедрой «Технология продуктов питания», Саратовский государственный аграрный университет имени Н.И. Вавилова. Россия.
410012, г. Саратов, Театральная пл., 1.

Тел.: (8452) 23-32-92; e-mail: popova@yandex.ru.

Ключевые слова: бруцеллез; сплит-конъюгированная вакцина; овцы, козы; реакция агглютинации (РА); Роз-Бенгал проба (РБП); реакция связывания комплемента (РСК); титры противобруцеллезных антител.

\title{
EXPERIMENTAL APPLICATION OF A SPLIT-CONJUGATED VACCINE AGAINST ANIMAL BRUCELLOSIS IN SMALL CATTLE
}

Veselovskiy Stepan Yuryevich, Candidate of Veterinary Sciences, Assistant of the chair "Animal Diseases and VeterinarySanitary Inspection", Saratov State Agrarian University named after N.I. Vavilov. Russia.

Agoltsov Valery Aleksandrovich, Doctor of Veterinary Sciences, Professor of the chair "Animal Diseases and VeterinarySanitary Inspection", Saratov State Agrarian University named af ter N.I. Vavilov. Russia.

Popova Olga Mihailovna, Doctor of Biological Sciences, Associate Professor, Head of the chair "Food Technology", Saratov State Agrarian University named after N.I. Vavilov. Russia.

Keywords: brucellosis; split-conjugated vaccine against animal brucellosis; sheep; goats; agglutination test (RA); Rose-Bengal probe; complement fixation reaction (RSK); anti-brucellosis antibody titres.

A study was made of the blood samples of small cattle for brucellosis with various serological reactions when testing a split-conjugated vaccine against animal brucellosis three and a half, four and $a$ half months and nine months after immunization. Positive reaction of small cattle to brucellosis in the complement fixation reaction and the agglutination reaction of $40.7 \%$ of sheep and goats, and 44.4\% of animals in Ros-Bengal after
3.5 months of vaccination. The vaccine has a high immunogenicity against goats, a high enough antibody titer in blood three and a half months after vaccination, when tested with agglutination and Rose-Bengal, breakdown was detected in $83.3 \%$ of animals, and in the complement fixation reaction it was $66.7 \%$, which will, in our opinion, effectively use this vaccine in the fight against goat brucellosis. Immunized sheep in the complementfixation reaction and Rose-Bengal assay reacted positively only in $33.3 \%$ of cases. When the agglutination reaction was established three and a half months after the introduction of the vaccine - in $28.6 \%$ of the animals, in connection with the data obtained, we recommend looking for new immunoprotectors capable of enhancing the humoral immune response of sheep to the antigen of the tested anti-brucellosis vaccine. Nine months after the vaccination of the split-conjugated vaccine in all blood samples of small cattle (sheep and goats) with all of the above reactions, there was no positive test, which indicates the disappearance and complement-binding and agglutinating antibodies from the bloodstream of animals, and thus the opportunity is given differentiate postvaccinal antibodies in the blood serum of animals, from post-infection, in the case of their detection within the time specified above.

\section{НАНОЧАСТИЦЫ СЕЛЕНА И МИЦЕЛЛЫ АНТИГЕНОВ ППД - СРЕДСТВА ПРОФИЛАКТИКИ ТУБЕРКУЛЕЗА}

\section{ВИДЯГИНА Олеся Сергеевна, Саратовский государственный аграрный университет}

имени Н.И. Вавилова

Изучены адъювантные свойства мицелл неионогенного детергента Triton $\mathrm{X}$-114 и липидов кищечной палочки, а также наночастии, селена при иммунизаиии антигенами диагностического препарата туберкулина (ППД). Исследовали образование антител против ППд и клеток Мусоbacterium bоvis ВCG при иммунизации белых мышей указанными конструкциями в сравнении с иммунизацией ППд, используя метод непрямого дот-иммуноанализа, а также иммунотурбидиметрически. Иммунизация мышей мицеллами липида E. coli Б-5 или Triton X-114, несущими ППд, приводит к более высокому образованию антител против антигенов туберкулина, чем при иммунизации самим ППд. Иммунизация всеми препаратами, включая ППд, приводит к образованию антител, распознающих клетки М. bovis ВCG, однако наиболее высокие титры антител наблюдаются в плазмах крови животных, получавших мищеллы липида Е. coli Б-5 или Triton X-114. Полученные результаты свидетельствуют о возможности использования мицелл и наночастиц, селена в качестве адъюванта для иммунизации антигенами микобактерий.

Введение. Туберкулопротеин (ППД) - аллерген микобактерий, представляющий собой смесь фильтратов культур микобактерий человеческого и бычьего типов, используемый для выявления заболевания туберкулезом человека и животных. В онлайн-базе референсных последовательностей протеинов UniProtKB [20] фигурирует целое семейство из 7 туберкулиноподобных протеинов (tuberculin related protein, tuberculin-like protein, tuberculin-active protein) молекулярных масс от 14,8 до 27,8 kDa, пять из которых имеют предсказанный трансмембранный домен. Наличие трансмембранных доменов позволяет использовать в качестве адъювантов неионогенные детергенты и структурные мембранные фосфолипиды.

Для солюбилизации гидрофобных антигенов предложены мицеллы на основе коммерческих детергентов Cremophor EL и RH [8]. В качестве мицеллообразователя (носителя липофильных антигенов) возможно использование также неионогенного детергента Triton X-114, способного избирательно сорбировать липопротеиды разной природы [11].

Липосомы на основе фосфолипида мембран - лецитина - с добавлением холестерола давно 
и успешно используются для иммунизации против самых разнообразных антигенов $[1,10]$. Однако использование лецитина и холестерола может быть затруднительно из-за их дороговизны, а также низкой стойкости препаратов при хранении. Поэтому поиск новых матриц для композиции мицелл представляется актуальным. Особенно перспективно использование мембранных липидов грамотрицательных бактерий и штаммов Escherichia coli кишечных палочек в силу их большой относительной концентрации в клетке и простоты выделения [18]. В настоящее время получены мицеллы из мембранных липидов кишечной палочки в качестве носителей различных биологически активных веществ, однако нам не удалось обнаружить сведений об использовании подобных липосом в качестве адъювантов.

Конъюгаты антигенов ППД с наночастицами коллоидного золота уже были использованы в качестве адъювантов для получения поликлональных антител, пригодных для идентификации антигенов ППД и микобактерий в световой и электронной микроскопии, а также в перспективе для получения протективного эффекта против микобактерий $[7,9,14]$. Однако использование коллоидного золота в качестве адъюванта может быть технически сложно [5], поэтому следует искать другие адъюванты для антигенов микобактерий, более доступные для практического использования. Частицы восстановленного селена используются в качестве адъювантов и средств доставки различных биологически активных веществ [3, 4, 21], что делает их кандидатами на роль адъювантов для антигенов микобактерий.

Целью исследования являлось изучение применимости мицелл на основе Тритона X-114 и липидов Escherichia coli Б-5, а также частиц восстановленного селена в качестве адъювантов для антигенов ППД при иммунизации животных против туберкулеза.

Методика исследований. В работе использовали штамм Escherichia coli Б-5 из коллекции Саратовского НИВИ, а также клетки штамма $M y$ cobacterium bovis BCG, высеянного из состава коммерческой лиофилизированной живой вакцины.

В качестве иммунизирующих препаратов применяли следующее.

1. Стандартный раствор ППд для млекопиmающих - коммерческий препарат туберкулина очищенного (ППД) для млекопитающих (ФКП «Курская биофабрика», г. Курск). При иммунизации животных использовали десятикратное разведение раствора ППД в растворе Хэнкса.

2. Препарат мицелл из липидов E. coli Б-5, несущзй антигены ППД (МЦ-Б-5). Структурные липиды E. coli Б-5 получали по модифицированному методу Фолча [17]. 10 млрд отмытых физиологическим раствором клеток E. coli Б-5 суспендировали в 10 мл смеси метанол/хлороформ (1:2), перемешивали на магнитной мешалке в течение 3 ч при комнатной температуре с последующим осаждением клеток и дебриса центрифугированием (10 000 g 20 мин). Супернатант, содержащий липиды, использовали для приготовления липосом путем гидратации липидной пленки. Концентрацию сухого вещества липидов в растворе метанол/хлороформ определяли высушиванием раствора структурных липидов с последующим взвешиванием образовавшейся пленки. В 10 мл раствора структурных липидов вносили 1 мл раствора ППД, тщательно перемешивали и высушивали под вакуумом на стекле в асептических условиях до образования сухой пленки. Полученную пленку механически, путем интенсивного пипетирования, суспендировали в 4 мл раствора Хэнкса до образования опалесцирующей суспензии.

3. Препарат мищелл Тритон X-114, несущий антигены ППД (МЦ-ТХ-114). При комнатной температуре в 1700 мкл раствора Хэнкса вносили 100 мкл Triton X-114 (ТХ-114), детергент суспендировали, в суспензию вносили 200 мкл стандартного раствора ППД. Таким образом получали препарат мицелл МЦ-ТХ114, содержащий 5 \% детергента Triton X-114.

4. Частиць восстановленного селена, несущие антигены ППД (Се-ППД). В качестве восстановителя при приготовлении частиц селена использовали тиосульфат натрия [13]. В 1300 мкл деионизованной воды вносили 400 мкл раствора 7,5 мг/мл селенистой кислоты, 100 мкл 30\%-го тиосульфата натрия; раствор выдерживали при комнатной температуре. Через 1 ч в суспензию формирующихся частиц восстановленного селена вносили 200 мкл стандартного раствора ППД, дополнительно инкубировали при комнатной температуре 4 ч.

Свойства препаратов ППД, МЦ-Б-5, МЦ-ТХ114 и Се-ППД. Для препаратов ППД, МЦ-Б-5 и МЦ-ТХ-114, потенциально имеющих мицеллярную природу, определена константа мицеллообразования в тесте с Кумасси R-250, состоящем в фотометрировании разведений препаратов на растворе Хэнкса с добавлением красителя Coomassie R-250 [19]. Готовили разведения указанных препаратов на растворе Хэнкса, а также мицелл Тритон $\mathrm{X}-114$, приготовленных как и для МЦ-ТХ-114, но не несущих антигенов ППД (МЦ чистая). К 200 мкл полученных разведений добавляли по 20 мкл 0,5 мг/мл раствора Кумасси R-250 на растворе Хэнкса; с помощью микропланшетного ридера определяли оптические плотности (ОП) при длинах волн 595 и 555 нм, вычисляли отношение ОП595/ ОП555, или «красный сдвиг». Об исчезновении мицеллярных структур в ряду разведений препаратов судили по исчезновению красного сдвига, т.е. по резкому падению отношения ОП595/ОП555.

Препарат МЦ-Б-5 исследовали микроскопически при окрашивании суданом черным Б. Высушенные на воздухе мазки погружали в 0,5\%-й раствор судана черного Б (Sigma-Aldrich) в 50\%-й уксусной кислоте на 10 мин, мазки однократно промывали фосфатно-солевым буфером (ФСБ) и микроскопировали под иммерсионным объективом при увеличении 1000х.

Получали электронные микрофотографии цельного препарата Се-ППД на просвечивающем электронном микроскопе Libra 120 (Carl Zeiss, 
Германия) при ускоряющем напряжении 120 кВ.

Иммунизация мышей. В опыте использовали самцов белых нелинейных мышей, по 10 гол. в

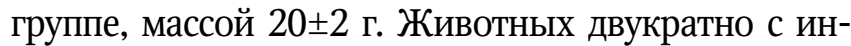
тервалом в неделю внутрибрюшинно иммунизировали свежеприготовленными препаратами МЦ-Б-5 (1250 мкл/кг массы тела), МЦ-ТХ-114 (2500 мкл/кг), Cе-ППД (2500 мкл/кг), ППД (2500 мкл/кг), контрольным животным вводили 2500 мкл/кг раствора Хэнкса. Доза антигенов препарата ППД для всех иммунизированных животных составляла по белку 1,2 мг/кг и по полисахариду 9 нг/кг. По истечении двух недель от первой иммунизации животных наркотизировали ингаляцией изофлурана и забивали декапитацией, получали перитонеальные клетки (ПК) и образцы гепаринизированной крови [2]; гепаринизированную кровь разделяли центрифугированием (800 g 15 мин) на форменные элементы и плазму. ПК, форменные элементы и плазму крови использовали для определения наличия антител против клеток M. bovis BCG и препарата ППД, а также подавления дыхания перитонеальных клеток в присутствии лимфоцитов.

Образование антител против клеток Mycobacterium bovis BCG. Оценку образования антител против клеток $M$. bovis BCG производили с помощью дотиммуноанализа [9]. Плазмы от экспериментальных животных дефибринировали инкубацией со стеклянными бусами и декомплементировали прогреванием (56 ${ }^{\circ} \mathrm{C} 15$ мин). На мембрану Immobilon-PSQ (Merck) наносили по 10 мкл 2 млрд КОЕ/мл суспензии M. bovis BCG в ФСБ рН 7,2, бактерии фиксировали высушиванием на воздухе, свободные участки мембраны блокировали инкубацией в течение 1 ч в 2\%-м растворе сухого молока в ФСБ. Мембраны с нанесенными бактериями инкубировали в 10-кратных разведениях исследуемых дефибринированных плазм на ФСБ в течение 5 ч при комнатной температуре; связанные с антигеном антитела выявляли инкубацией в 10-кратном разведении конъюгата коллоидного золота с белком А (предоставлено Л.А. Дыкманом) на ФСБ в течение ночи.

Образование антител против ППД. Наличие антител против антигенов ППД в дефибринированных образцах плазмы от экспериментальных животных оценивали иммунотурбидиметрически и твердофазным дот-иммуноанализом.

Наличие антител против антигенов ППД подтверждали непрямым дот-иммуноанализом с использованием коллоидного золота на поливинилиденфторидной мембране (PVDF) (Western S; Millipore, США) [7]. Двукратные разведения стандартного раствора ППД, начиная от цельного до разведения 1:64, наносили на PVDF в виде пятен по 10 мкл. Дот-иммуноанализ далее производили, как и для клеток M. bovis BCG.

При проведении иммунотурбидиметрического анализа образцы дефибринированной плазмы троекратно титровали на буфере ФСБ $\mathrm{pH}$ 7,4 с 4\%-м полиэтиленгликолем 8000 (ПЭГ), вносили по 20 мкл разведений в лунки планшета, до- бавляли по 180 мкл ППД, разведенного 1/9 ФСБ; инкубировали 10 мин при комнатной температуре. В планшете в момент внесения ППД и после инкубации устанавливали ОП при 340 нм, определяя преципитацию как приращение ОП340 после инкубации над исходной ОП340.

Влияние иммунизации на метаболическую активность перитонеальных клеток в присутствии лимфоиитов при фагоциттозе клеток M. bovis BCG in vitro. Определяли метаболическую активность перитонеальных клеток при заражении их in vitro живыми клетками M. bovis BCG, а также при соинкубации зараженных ПК с лимфоцитами (ЛЦ) in vitro по оригинальной методике. Для определения метаболической активности ПК использовали тест восстановления нитросинего тетразолия (НСТ-тест) [6]. Из форменных элементов образцов гепаринизированной крови экспериментальных животных центрифугированием на Ficoll-Paque (Pharmacia) (800g 15 мин) получали лимфоциты. ЛЦ отмывали раствором Хэнкса (800 g 15 мин) и ресуспендировали до концентрации $10^{6}$ клеток/мл в среде ДМЕМ с добавлением 20 \% плазмы от этого же животного (аутологическая плазма). Перитонеальные клетки отмывали раствором Хэнкса и ресуспендировали в среде ДМЕМ с 20 \% аутологической плазмы до концентрации 10 млн/мл. В аликвоты ПК добавляли живые клетки $M$. bovis BCG до финальной концентрации $10^{8}$ КОЕ/мл, вносили равные объемы свежей среды ДМЕМ с 20 \% аутологической плазмы или суспензий ЛЦ от соответствующего животного.

Аликвоты суспензий лейкоцитов инкубировали в течение 16 ч при $37^{\circ} \mathrm{C}$. По окончании инкубации в суспензии лейкоцитов вносили раствор 0,1\%-го нитросинего тетразолия в среде ДМЕМ до финальной концентрации 0,01 \%, инкубировали 1 ч при $37^{\circ} \mathrm{C}$. ЛЦ и ПК разделяли центрифугированием на Ficoll-Paque (Pharmacia) (800 g 15 мин) (800 g 15 мин), ЛЦ отбрасывали, ПК отмывали раствором Хэнкса. Осадки ПК экстрагировали диметилсульфоксидом, в полученных экстрактах при 492 нм фотометрически определяли концентрацию формазана в пересчете на $10^{6}$ ПК.

Результатьи исследований. Свойства иммунизирующих препаратов. Препарат ППД, использованный для получения иммунизирующих

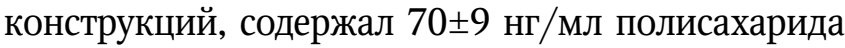
и $10 \pm 1$ мг/мл белка. Концентрация липида E. coli в мицеллярных препаратах составляла 50 мг/мл. Критическая константа образования мицелл соответствовала 0,015 \%. Результаты иммерсионной микроскопии окрашенных суданом черным Б мицелл приведены на рис. 1.

По данным электронной микроскопии (рис. 2) определяли средний размер селеновых коллоидов, составляющий 64+18 нм. Частицы селена связаны между собой электронно-прозрачным материалом, вероятно, теми или иными субстанциями из состава препарата ППД.

Наличие в плазме крови экспериментальных животных антител против антигена ППД. Результат$$
\text { сотлых антител против антигена ППцд. Результат }
$$ 


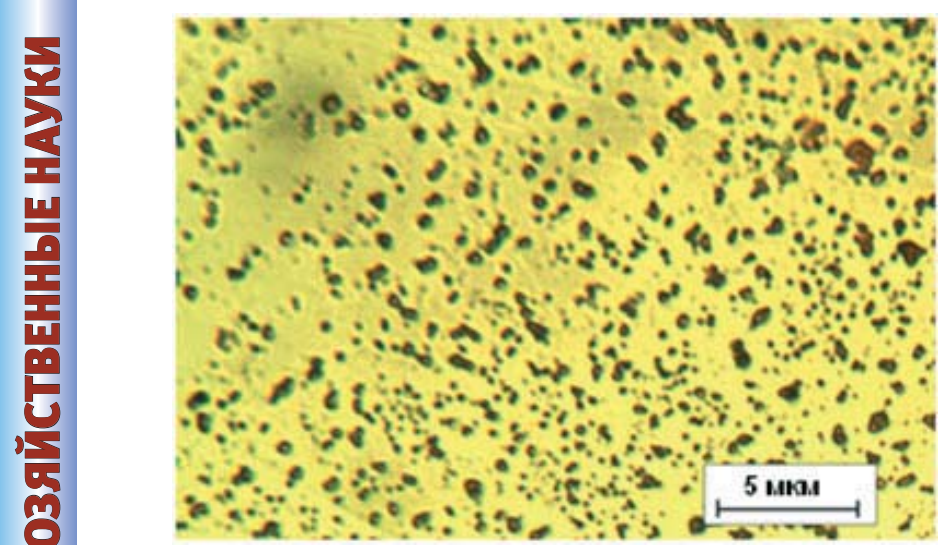

Рис. 1. Световая микроскопия окрашенного суданом черным Б препарата МЦ-Б-5. Иммерсионный объектив, $\times 1000$

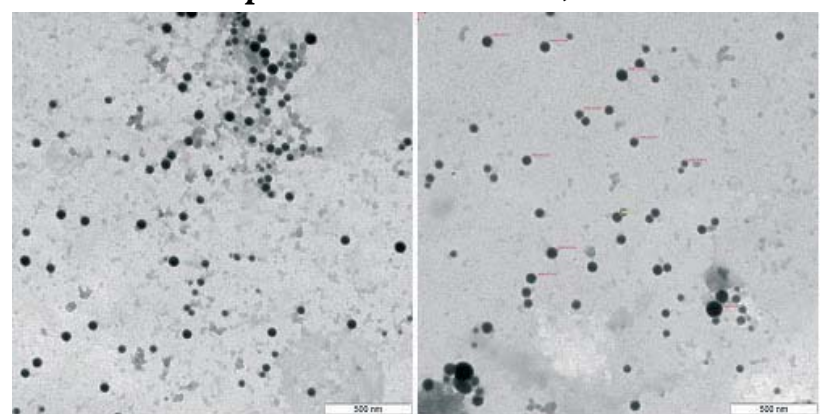

Рис. 2. Электронная трансмиссионная микроскопия частиц, препарата Се-ППД

иммунотурбидиметрического исследования и дотиммуноанализа на PVDF-мембране антител (AT) против антигенов (АГ) препарата ППД представлен на рис. 3. Антитела против ППД с некоторой интенсивностью выявляли и у животных контрольной группы. При этом иммунизация животных препаратами, несущими антигены ППД (МЦ-Б-5, МЦ-ТХ-114, Се-ППД), и сам препарат ППД, вызывают рост их концентрации. Об этом свидетельствует интенсивность окраски нанесений антигена конъюгатом коллоидного золота с белком А.

Согласно результатам иммунотурбидиметрического исследования, наиболее сильно стимулирует образование антител против антигенов препарата ППД иммунизация препаратом МЦ-Б-5, а также МЦ-ТХ114. Иммунизация препаратом Се-ППД приводит к образованию антител несколько меньшему, чем при иммунизации самим препаратом ППД.

Результаты дот-иммуноанализа $M$. bovis BCG приведены на рис. 4. Иммунодот с плазмой от контрольных животных практически не дает характерного окрашивания микобактерий. Иммунизация же мышей всеми исследуемыми иммунизирующими конструкциями приводит к образованию антител, распознающих клетки M. bovis BCG, о чем свидетельствует окрашивание клеток бактерии связанными золотыми наночастицами. Результаты исследования метаболической активности макрофагов в НСТ-тесте при их заражении живыми клетками M. bovis BCG и соинкубации с лимфоцитами периферической крови приведены на рис. 5.

Фагоцитоз M. bovis BCG перитонеальными клетками практически не сказывается на метаболизме последних, однако соинкубация ПК с лимфоцитами заметно снижает их метаболизм. Концентрация

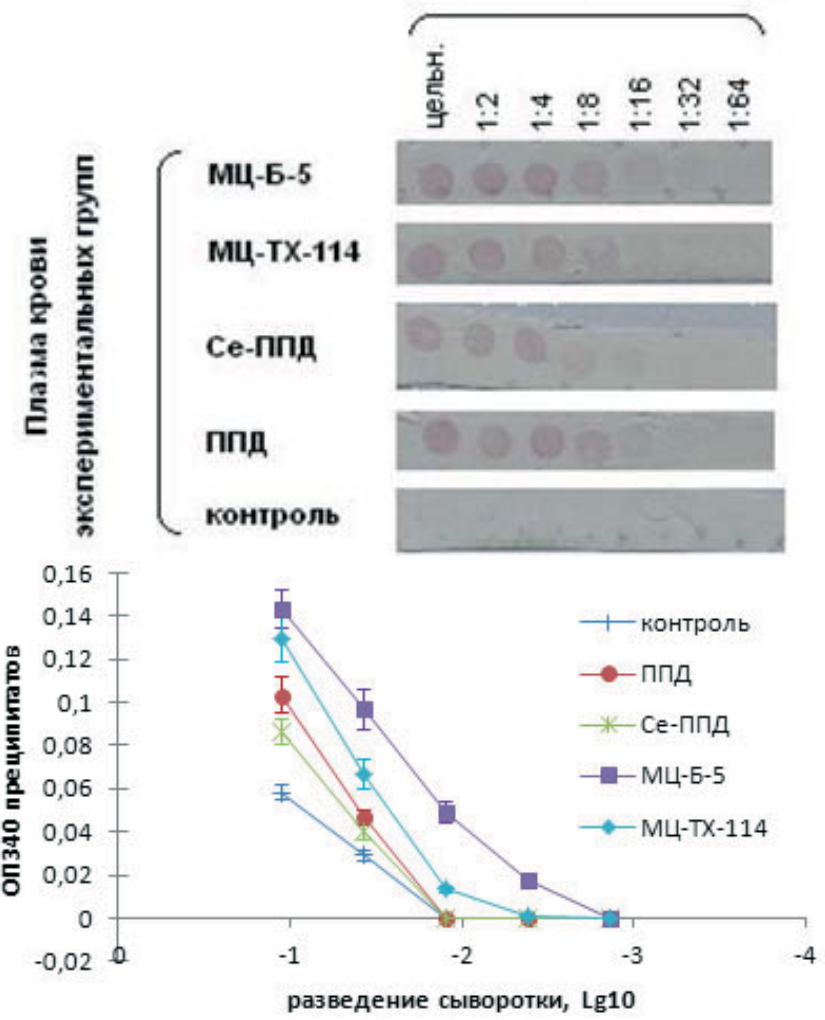

Рис. 3. Наличие АТ против АГ ППД

по результатам дот-иммуноанализа и иммунотурбидиметрического исследования плазм животных экспериментальных групп

накопленного формазана в фагоцитировавших ПК с лимфоцитами периферической крови у животных групп МЦ-Б-5, МЦ-ТХ-114 и Се-ППД достоверно ниже таковой в сравнении сПК из суспензии, свободной от микобактерии $(p<0,05)$. При этому животных указанных групп накопление формазана фагоцитировавшими ПК в присутствии ЛЦ достоверно ниже контроля $(p<0,05)$. Приведенные данные говорят о подавлении метаболической активности макрофага при соинкубации с ЛЦ в результате иммунизации МЦ-Б-5, МЦ-ТХ-114 и Се-ППД в сравнении с ППД, причем подавление метаболизма у ПК животных группы Се-ППД выше, чем у группы ППД, несмотря на более слабое у них образование антител против антигенов ППД при иммунизации.

Общеизвестным фактом является внутриклеточный паразитизм микобактерий в макрофагах,

разведения культуры мара. КОЕ/ма M. bovis BCG 2 цельная $1: 2 \quad 1: 4 \quad 1: 8 \quad 1: 16 \quad 1: 32 \quad 1: 64 \quad 1: 128$

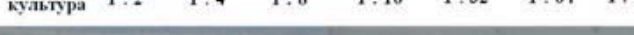

Mщ-6-5

M世-TX-114

Сe-IIIIम

ІІІम

Контроль

Рис. 4. Результаты дот-иммуноанализа наличия AT против клеток М. bоvis ВСG в плазмах крови животных экспериментальных групп 


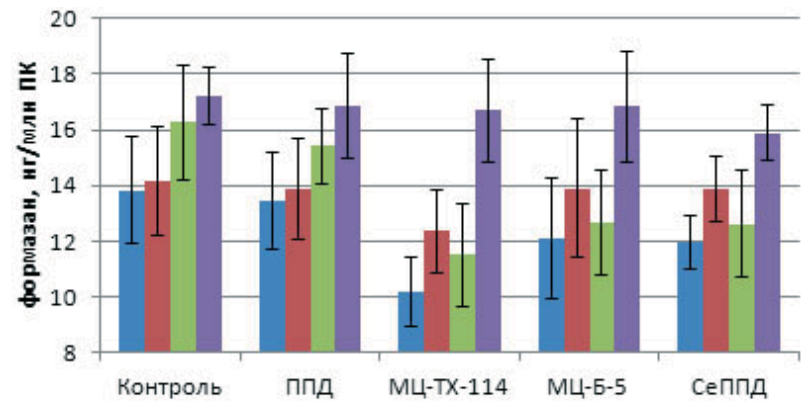

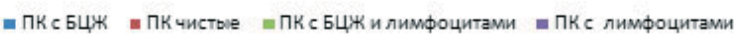

Рис. 5. Метаболическая активность Пк в чистой суспензии и при соинкубации их c M. bovis ВCG (БЦЖ), а также совместно с лимфоцитами периферической крови

моноцитах и дендритных клетках [19]. Натуральные лимфоциты-киллеры способны убивать микобактерий внутри зараженных моноцитов [11], а Т-лимфоциты способны убивать макрофагов, несущих живых M. tuberculosis [13]. Между дендритными клетками и $\gamma \delta$-Т-клетками, осуществляющими иммунный ответ на $M$. tuberculosis, устанавливается взаимная стимуляция. В частности, зараженные дендритные клетки стимулируют цитотоксическую активность лимфоцитов, причем адъюванты могут быть выбраны исходя из их способности стимулировать $\gamma \delta$-Т-клетки, что должно приводить к оптимизации иммунитета, обусловленного CD8 T-клетками [14]. В нашем случае в эксперименте участвовала вся популяция лимфоцитов, поэтому достаточно трудно вычленить эффект той или иной субпопуляции лимфоцитов. Однако, несмотря на это, очевидно, что иммунизация препаратами МЦ-Б-5, МЦ-ТХ-114 и Се-ППД приводит к подавлению метаболической активности зараженного микобактерией макрофага лимфоцитами периферической крови. Это позволяет говорить о перспективности исследований частиц восстановленного селена, мицелл на основе Тритона TX-114 или липидов кишечной палочки в качестве адъювантов при иммунизации против микобактерий туберкулеза.

Заключение. В качестве адъюванта при иммунизации аллергенами $M$. tuberculosis и $M$. bovis возможно использование мицелл на основе Тритон $\mathrm{X}-114$ или липидов Escherichia coli Б-5, что приводит к росту концентрации антител, способных распознавать антигены туберкулина и клеток микобактерии.

Представляется перспективным исследование мицелл на основе Тритон X-114 или липидов клеток E. coli Б-5, а также наночастиц восстановленного селена, несущих антигены ППД, в качестве адъюванта для коррекции взаимодействия фагоцитов и лимфоцитов при иммунологическом ответе на патогенные микобактерии.

\section{СПИСОК ЛИТЕРАТУРЫ}

1. Адъюванты в современной вакцинологии Е.Ю. Исаенко [и др.] // Annals of Mechnikov Institute. 2013. - № 4. - C. 5-21.

2. Биргер М.О. Справочник по микробиологическим и вирусологическим методам исследования. - М.: Медицина, 1967. - 464 с.

3. Использование наночастиц селена в качестве наноносителя лекарственных веществ и антигенов на примере адъюванта при иммунизации животных против колибактериоза / К.П. Габалов [и др.] // Ветеринарная патология. - 2016. - Т. 3. - № 57. - С. 29-37.

4. Козлов С.В. Конструирование коллоидного комплекса селена с лактоферрином и изучение его биодинамических свойств // Актуальные вопросы ветеринарной биологии. - 2012. - № 1. - С. 27-32.

5. Конструирование конъюгатов коллоидного селена и коллоидного золота с белком вируса гриппа и изучение их иммуногенных свойств / П.В. Меженный [и др.] // Вестник Саратовского госагроуниверситета им. Н.И. Вавилова. - 2013. - № 2. - С. 29-32.

6. Маянский А.Н., Виксман М.К. Способ оценки функциональной активности нейтрофилов человека по реакции восстановления нитросинего тетразолия. Казань: Изд-во Казан. мед. ун-та, 1979. - 11 с.

7. Разработка иммунозолотых диагностических систем для идентификации возбудителя туберкулеза in situ / C.A. Староверов [и др.] // Российский ветеринарный журнал. Мелкие домашние и дикие животные. - 2011. - № 2. - С. 29-32.

8. Староверов С.А., Семенов С.В. Адъювант для биопрепаратов // Патент РФ № 2214278. 2003.

9. Староверов С.А., Дыкман Л.А. Использование наночастиц золота для получения антител к туберкулину, иммуноанализа микобактерий и вакцинации животных // Российские нанотехнологии. - 2013. T. 8. - № 11-12. - C. 118-122.

10. Benvegnu T., Lemiègre L., Cammas-Marion S. Formulation of a New Generation of Liposomes from Bacterial and Archeal Lipids // Tropical Journal of Pharmaceutical Research, 2016, Vol. 15, No. 2, P. 215-220.

11. Bordier C. Phase Separation of Integral Membrane Proteins in Triton X-114 Solution // J Biol Chem., 1981, Vol. 256, No. 4, P. 1604-1607.

12. Brill K.J., Li Q., Larkin R., Canaday D.H., Kaplan D.R., Boom W.H., Silver R.F. Human Natural Killer Cells Mediate Killing of Intracellular Mycobacterium tuberculosis H37Rv via Granule-Independent Mechanisms // Infect. Immun. 2001. Vol. 69, No. 3, P. 1755-1765.

13. Chen Y-H., Chang H.P., Lin. Z.H., Wang C.R. Size effect of colloidal selenium particles on the inhibition of LPS-induced nitric oxide production // Journal of the Chinese Chemical Society, 2005, No. 52, P. 389-399.

14. Dieli F., Troye-Blomberg M., Ivanyi J., Fourniè J.J., Bonneville M., Peyrat M.A., Sireci G., Salerno A. Vgamma9/Vdelta2 T lymphocytes reduce the viability of intracellular Mycobacterium tuberculosis // Eur. J. Immunol., 2000, Vol. 30, No. 5, P. 1512-1519.

15. Dieli F., Caccamo N., Meraviglia S., Ivanyi J., Sireci G., Bonanno C.T., Ferlazzo V., Mendola C., Salerno A. Reciprocal stimulation of $\gamma \delta \mathrm{T}$ cells and dendritic cells during the anti-mycobacterial immune response // Eur. J. Immunol., 2004, No. 34, P. 3227-3235.

16. Dykman L.A., Bogatyrev V.A. Gold nanoparticles: preparation, functionalisation and applications in biochemistry and immunochemistry // Russian Chemical Reviews, 2007, Vol. 76, No. 2, P. 181-194.

17. Folch J., Lees M., Sloane Stanley G.H. A simple method for the isolation and purification of total lipids from animal tissues // J Biol Chem., 1957, No. 226, P. 497-509.

18. Gidden J., Denson J., Liyanage R., Ivey D.M., Lay J.O. Lipid Compositions in Escherichia coli and Bacillus subtilis During Growth as Determined by MALDITOF and TOF/TOF Mass Spectrometry // Int. J. Mass Spectrom, 2009, Vol. 283, P. 178-184.

19. Kleinschmidt J. H., Wiener M. C., Tamm L. K. Outer membrane protein A of $E$. coli folds into detergent micelles, but not in the presence of monomeric detergent // Protein Sci,1999, No. 8, P. 2065-2071. 
20. Meena L.S. Survival mechanisms of pathogenic Mycobacterium tuberculosis H37Rv / / FEBS Journal, 2010, No. 277, P. 2416-2427.

21. URL: http://www.uniprot.org/ (дата обращения 05.07.17).

Видягина Олеся Сергеевна, аспирант кафедры «Болезни животных и ветеринарно-санитарная экспертиза», Саратовский государственный аграрный университет имени Н.И. Вавилова. Россия.

410012, г. Саратов, Театральная пл., 1.

Тел.: (8452) 69-25-32.

Ключевые слова: наночастицы селена; мицеллы; иммунизация; туберкулин; Мусоbacterium bovis $B C G$.

\title{
SELENIUM NANOPARTICLES AND MICELLS ARE TOOLS FOR TUBERCULOSIS PREVENTION
}

Vidyagina Olesya Sergeevna, Post-graduate Student of the chair "Animals" Diseases and Veterinarian-sanitarian Expertise", Saratov State Agrarian University named after N.I. Vavilov. Russia.

Keywords: selenium nanoparticles; micelles; immunization; Mycobacterium bovis BCG.

The adjuvant properties of micelles of nonionic detergent and $E$. coli lipids, as well as of selenium nanoparticles, were studied in the course of immunization with antigens of the diagnostic tuberculin. The formation of antibodies against PPD and Mycobacterium bovis BCG cells was studied in immunization of white mice with these constructs in comparison with the PPD immunization, using the indirect dot-immunoassay method, as well as immunoturbodimetrically. Immunization of mice with E. coli B-5 lipid or Triton X-114 micelles bearing PPD leads to the formation of antibodies against tuberculin antigens higher than for immunization with PDD itself. Immunization with all drugs, including PPD, leads to the formation of antibodies that recognize M. bovis BCG cells, but the highest levels of antibodies are observed in the blood plasma of animals receiving lipid $E$. coli B-5 or Triton X-114 micelles. The obtained results indicate the possibility of using micelles and selenium nanoparticles as an adjuvant for immunization with mycobacterial antigens.

DOI

\section{ПРОТЕОЛИТИЧЕСКИЕ ФЕРМЕНТЫ ЗЕРНА ТРИТИКАЛЕ, ПРОШЕДШЕГО УВЛАЖНЕНИЕ И ПОДСУШИВАНИЕ}

\author{
Витол Ирина Сергеевна, ВНИИЗ - филиал ФГБНУ «ФНЦ пищевых систем \\ им. В.М. Горбатова» РАН \\ ГЕРАСИНА Анна Юрьевна, ВНИИЗ - филиал ФГБНУ «ФНЦ пищевых систем \\ uм. B.М. Горбатова» РАН
}

Показано, что нейтральные протеиназы в зерновке тритикале распределены неравномерно: в зародыше сосредоточена основная часть ферментов, их активность в 5,2-6,5 раза превосходит активность в иелом зерне. Установлено, что увлажнение зерна приводит к нарастанию активности нейтральных протеиназ при влажности 30 \% она выше исходной на 60-80 \% (для иелого зерна). В зародыше активность ферментов быстро нарастает и при влажности 20 \% достигает максимума, увеличиваясь в 1,5-2,0 раза. В зерновке без зародыша активность нейтральных протеиназ при влажности 30 \% составляет 118 и $120 \%$ от исходной. Подсушивание увлажненного зерна сопровождается снижением активности нейтральных протеиназ, но остается более высокой (на 15-25\%) по сравнению с зерном исходной влажности.

Введение. Тритикале - новый вид хлебных злаков, обладающий высоким биологическим потенциалом и пищевой ценностью $[5,8,10,12,13]$. Использование тритикале как продовольственной культуры в нашей стране остается до сих пор крайне ограниченным. Однако это перспективное направление расширения сырьевой базы и ассортимента выпускаемой продукции для перерабатывающих отраслей пищевой индустрии, что подтверждается повышенным интересом к данной культуре как со стороны исследователей, так и со стороны производителей пищевых продуктов $[3,4,7,11,12]$.

Качество зернового сырья определяется не только его химическим составом, но и состоянием ферментного комплекса $[1,12]$. Известно, что повышение влажности зерна сопровождается интенсивным нарастанием активности ферментов [6]. Зерно выходит из состояния покоя, в нем получают развитие пусковые механизмы прорастания. Глубина развития этих процессов зависит прежде всего от количества поглощенной воды. Дальнейшее подсушивание зерна приводит к снижению его физиологической активности, при этом ферментные системы не возвращаются в исходное состояние. Изучение важнейших ферментных систем зерна при увлажнении и подсушивании имеет большое значение для оценки не только семенных достоинств зерна, но и технологических показателей.

Процесс увлажнения и подсушивания зерна изучали зарубежные и отечественные исследователи, в первую очередь с точки зрения его гидротермической обработки (ГТО) и дальнейшей переработки на мукомольных предприятиях [2], а также с точки зрения возможности получения различных типов тритикалевого солода для технологий бродильных производств [4]. Изучение протеолитических ферментов зерна тритикале при разных физиологических состояниях представляет не только практический интерес получения «биоактивированного» зерна. Это позволит приблизиться к пониманию роли отдельных ферментных систем в сложных пусковых механизмах прорастания. 